\title{
A Cross-Sectional Study of Detection of Beta Globin (HBB) Haplotypes Among Beta Thalassemia Patients
}

\author{
Ali Alsamiri ${ }^{1}$, Fatma Alzahrani ${ }^{2}$, Najlaa Filimban ${ }^{1}$, Ammar Khojah ${ }^{1}$, Raed Felimban ${ }^{1}$, Talal Qadah ${ }^{1}$ \\ 1. Medical Laboratory Technology, King Abdulaziz University - Faculty of Applied Medical Sciences, Jeddah, SAU 2. \\ Pediatrics, King Abdulaziz University Hospital, Jeddah, SAU
}

Corresponding author: Talal Qadah, thqadah@kau.edu.sa

\section{Abstract \\ Introduction}

Beta-thalassemia is among the most common monogenic disorders in the Arabian Peninsula. This study aimed to investigate the $\beta$-globin (HBB) haplotypes among $\beta$-thalassemia patients in Saudi cohort which have potential implications in understanding the clinical care of patients and population genetic factors associated with $\beta$-thalassemia.

\section{Methods}

We analyzed $60 \beta$-thalassemia patients. Male/female distribution for $\beta$-thalassemia was 58.33\%/41.66\%. Results of hematological parameters and indices were obtained from the database. HBB haplotyping assay was performed for four specific loci of the HBB gene cluster using polymerase chain reaction-restriction fragment length polymorphism (PCR-RFLP) technique.

\section{Results}

HBB haplotyping assay identified three novel patterns namely haplotype 1, haplotype 2, and haplotype 3 and three common African haplotypes including Benin, Senegal, and Cameron. The frequency of haplotype 1 was the highest among the studied samples $(62 \%, \mathrm{n}=37)$ with $56.76 \%(\mathrm{n}=21)$ observed in males compared to 43.24\% $(\mathrm{n}=16)$ in females. This was followed by Senegal, haplotype 2, Benin and haplotype 3 with similar percentage, and Cameron haplotype with $18 \%, 12 \%, 3 \%$ and $2 \%$, respectively. The relationship between these haplotypes and various hematological parameters was calculated and our study found no significant relationship ( $\mathrm{p}$-value $>0.05$ ).

\section{Conclusion}

Our study indicated the importance of finding out types of $\beta$-globin haplotypes as novel types being discovered. Though no statistically significant association was identified among all the haplotypes in terms of hematological parameters, Cameroon or Benin haplotypes had the mildest form because they have the highest means among all parameters. Further studies need to be carried out on a larger population to detect the frequency of each specific mutation in each haplotype among $\beta$-thalassemia patients. This would help to re-address the question of the origin(s) of the $\beta$-thalassemia.

\section{Introduction}

Thalassemia syndromes are a heterogeneous group of inherited anemias characterized by a defective biosynthesis of the alpha $(\alpha)$ or beta ( $\beta$ ) globin subunits of the normal adult hemoglobin HbA (a2 $\beta 2)$. This defect can cause the formation of abnormal hemoglobin molecules resulting in low hemoglobin level. This group of inherited disorders is relatively common worldwide and considered as the most common singlegene disorders [1]. It is commonly found in the Mediterranean area, Middle East, Equatorial Africa, and Southern Asia and the clinical severity varies greatly from asymptomatic to severe hemolytic anemia.

$\beta$-thalassemia is considered as one of the most common monogenic disorders in Saudi Arabia. This is in fact due to the high percentage of consanguineous marriages [2]. It constitutes one of the major public health issues encountered by the ministry of health due to its high impact on clinical management costs [3]. The prevalence of $\beta$-thalassemia in Saudi Arabia is estimated to be $1.36 \%$ where $0.07 \%$ represents the major type and $1.29 \%$ represents the trait (minor) type [4,5]. Various studies on the prevalence of $\beta$-thalassemia conducted over 20 years demonstrated that the Eastern province has the highest number of cases [6]. Molecular pattern of $\beta$-thalassemia showed a wide spectrum of mutations affecting the HBB and novel 
mutations are being discovered as the diagnostic tools are becoming more advanced [7]. It is noteworthy to mention that even though $\beta$-thalassemia is highly prevalent in the Eastern Province, a wide spectrum of clinical symptoms for this disorder is reported from the Western Province [8]. This variation could be contributed to the differences in the $\beta$-globin gene (HBB) haplotypes.

\begin{abstract}
A haplotype can be defined as a set of genes of one chromosome that have been inherited together from a single parent [9]. HBB haplotypes settle on different combinations of polymorphic sites of HBB through the non-random link of the single point called restriction fragment length polymorphism (RFLP) [10]. Several mutations are found within and around HBB, resulting in different types of HBB haplotypes and thus causing population diversity [11]. The diversity in HBB haplotypes reflects the evolutionary and genetic relationship among this disorder in different ethnic backgrounds [12]. The importance of identification of HBB haplotype comes through the determination of DNA sequence variation across geographical populations. Those variations often caused by the transmission of genetic variations through populations from one generation to the next [13].
\end{abstract}

In Saudi Arabia, few studies have been performed to explore the molecular patterns of $\beta$-thalassemia [1416]. In this study, we aimed to determine the HBB haplotypes among $\beta$-thalassemia patients in the Saudi cohort and correlate between these haplotypes and red cell parameters.

\title{
Materials And Methods
}

\section{Sample collection and laboratory investigation}

A total number of 60 blood samples from previously diagnosed $\beta$-thalassemia patients were obtained after consents were signed. The gender distribution included 25 (41.66\%) females and 35 (58.33\%) males. Hematological investigations were recorded through complete blood count (CBC) and Hb separation. The study was approved by the Ethics and Research Committee at Faculty of Applied Medical Sciences, King Abdulaziz University (Ref. No. FAMS-2019-003).

\section{DNA extraction and preservation}

DNA extraction was carried out using the Wizard ${ }^{\circledR}$ Genomic DNA Purification Kit (Promega, Madison, WI, USA) according to the manufacturer's instruction. The DNA concentration of the samples was assessed using Nanodrop 2000 spectrophotometer (Thermo Fisher Scientific, Waltham, MA, USA) and stored at $-20^{\circ} \mathrm{C}$ for subsequent analyses.

\section{$\beta$-globin (HBB) haplotyping assay}

HBB haplotyping assay was performed for four specific loci of the HBB gene cluster using polymerase chain reaction-restriction fragment length polymorphism (PCR-RFLP) as previously described by Sutton et al. [17]. Briefly, the four loci were amplified by specific primer sets to generate PCR fragments of $655 \mathrm{bp}, 771 \mathrm{bp}, 766$ bp and $388 \mathrm{bp}$ for primer set numbers 1, 2, 3 and 4 respectively as shown in Table 1 . These fragments

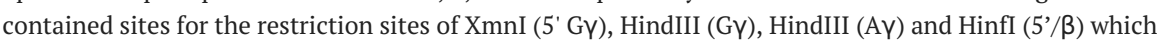
were digested by the restriction enzymes. Identification of HBB haplotypes was determined through positive and/or negative reactions to digestion with restriction enzymes at these loci in order to generate specific patterns of a haplotype as demonstrated in previous works [18, 19].

\begin{tabular}{|c|c|c|c|c|}
\hline Primers & Sequence & Position & Polymorphic site & Gene \\
\hline \multirow{2}{*}{1} & F- AACTGTTGCTITATAGGATTIT & 33880 & \multirow{2}{*}{ Xmnl 34330} & \multirow{2}{*}{ 5' Gy } \\
\hline & R- AGGAGCTTATTGATAACTCAGAC & 34535 & & \\
\hline \multirow{2}{*}{2} & F- TGCTGCTAATGCTTCATTACAA & 35440 & \multirow{2}{*}{ HindllI 35785} & \multirow{2}{*}{ Gy } \\
\hline & R- AAGTGTGGAGTGTGCACATGA & 36211 & & \\
\hline \multirow{2}{*}{3} & F- IGCIGCIAAIGCIICAIIACAA & $403 / 1$ & \multirow{2}{*}{ HindIII 40731} & \multirow{2}{*}{$A \gamma$} \\
\hline & R- TAAATGAGGAGCATGCACACAC & 41137 & & \\
\hline \multirow{2}{*}{4} & F-CTACGCTGACCTCATAAATG & 60958 & \multirow{2}{*}{ Hinfl 61199} & \multirow{2}{*}{$5 / \beta$} \\
\hline & R- CTAATCTGCAAGAGTGTCT & 61341 & & \\
\hline
\end{tabular}

TABLE 1: Sequence of primer, position and polymorphic site 


\section{Cureus}

\section{Statistical analysis}

All statistical analysis in this study was carried out using either one-way ANOVA or Kruskal-Wallis test using SPSS, version 22 (IBM Corp., Armonk, NY, USA). A p-value $<0.05$ was considered statistically significant. Regression analysis was used to study the association of HBB haplotypes with changes in the hematological parameters including red blood cell count (RBC), hemoglobin (Hb), hematocrit (Hct), mean cell volume (MCV), mean cell hemoglobin (MCH), mean cell hemoglobin concentration (MCHC), and red cell distribution width (RDW). Post hoc analysis was performed to find statistical significance among or in between the groups.

\section{Results}

Recognition patterns of HBB haplotype generated from digestion of amplified regions with the restriction enzymes showed some common African haplotypes including Benin, Senegal, and Cameron while three other novel patterns namely haplotype 1 , haplotype 2 , and haplotype 3 were identified (Table 2 ). We found that the frequency of haplotype 1 was the highest with $62 \%(\mathrm{~N}=37)$ with a mild predominance of males $(56.76 \%, \mathrm{n}=21)$ compared to females $(43.24 \%, \mathrm{n}=16)$. This was followed by Senegal haplotype $(18 \%, \mathrm{~N}=$ $11), \mathrm{H} 2(12 \%, \mathrm{~N}=7)$, Benin $(3 \%, \mathrm{~N}=2), \mathrm{H} 3(3 \%, \mathrm{~N}=2)$ and Cameroon $(2 \%, \mathrm{~N}=1)$ as shown in Figure 1.

\begin{tabular}{|c|c|c|c|c|}
\hline Haplotype & Xmnl 5' Gy & HindIII Gy & HindIII $A \gamma$ & Hinfl 5' $\beta$ \\
\hline Benin & - & - & - & - \\
\hline Senegal & + & + & - & + \\
\hline Cameroon & - & + & + & + \\
\hline Haplotype 1 & - & - & - & + \\
\hline Haplotype 2 & - & + & - & + \\
\hline Haplotype 3 & + & + & + & + \\
\hline
\end{tabular}

\section{TABLE 2: Pattern of HBB haplotypes according to restriction enzyme}

HBB: $\beta$-globin

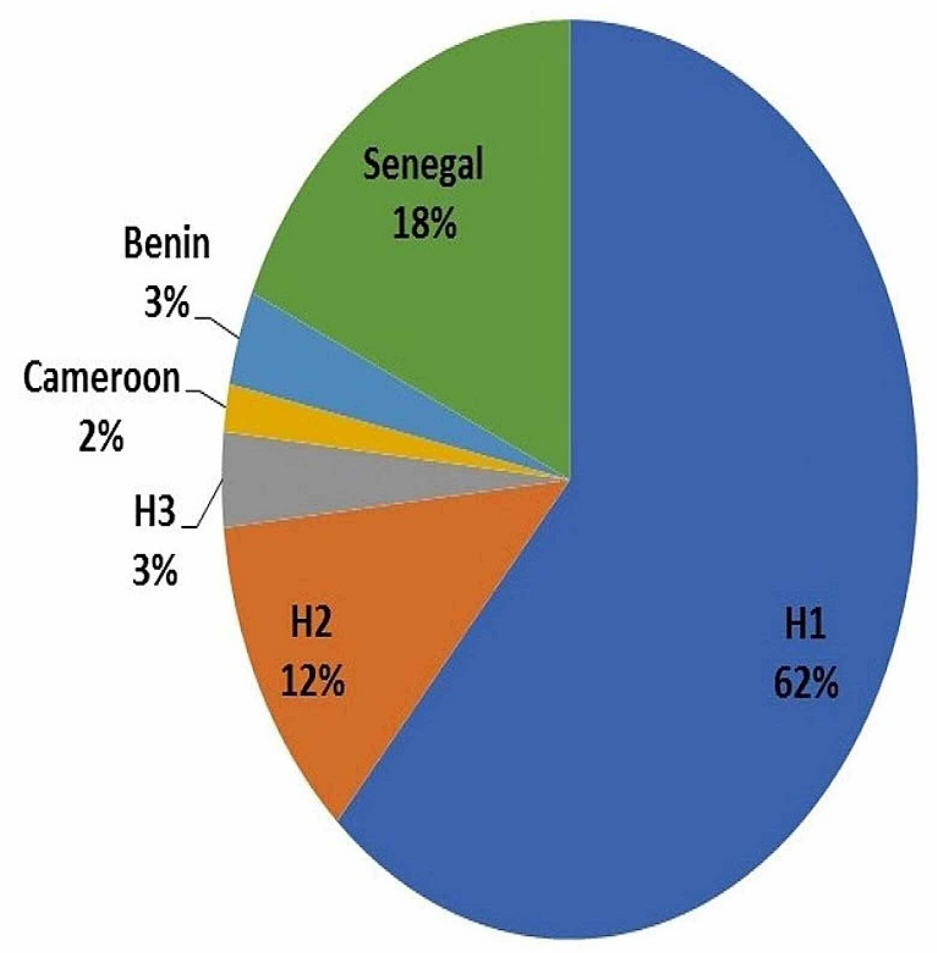




\section{Cureus}

FIGURE 1: Frequency of HBB haplotypes. The pie chart shows the percentage of observed haplotypes

HBB: $\beta$-globin

The association of red cell parameters among the various haplotypes of the cohort study was investigated and the results indicated that there is no statistically significant relationship between the haplotypes in terms of hematological parameters as all showed no significant scores (p-values above 0.05) (Table 3).

\begin{tabular}{|c|c|c|c|c|c|c|c|}
\hline $\begin{array}{l}\text { Hematological } \\
\text { parameters }\end{array}$ & $\begin{array}{l}\text { Cameroon }(\mathrm{N}= \\
1,1.66 \%)\end{array}$ & $\begin{array}{l}\text { Benin ( } N=2 \text {, } \\
3.33 \%)\end{array}$ & $\begin{array}{l}\mathrm{H1}(\mathrm{N}=37 \\
61.66 \%)\end{array}$ & $\begin{array}{l}\mathrm{H} 2(\mathrm{~N}=7, \\
11.66 \%)\end{array}$ & $\begin{array}{l}\text { H3 (N = 2, } \\
3.33 \%)\end{array}$ & $\begin{array}{l}\text { Senegal }(N=11 \text {, } \\
18.33 \%)\end{array}$ & $\begin{array}{l}\text { P-value } \\
\text { KW }\end{array}$ \\
\hline $\operatorname{RBC}\left(\times 10^{6} / \mu \mathrm{L}\right)$ & 3.20 & $2.98 \pm 0.21$ & $2.99 \pm 0.99$ & $2.88 \pm 1.30$ & $2.26 \pm 0.41$ & $3.03 \pm 0.63$ & 0.644 \\
\hline $\mathrm{Hb}$ (g/dl) & 10.4 & $9.60 \pm 0.70$ & $7.39 \pm 2.51$ & $5.85 \pm 1.90$ & $5.35 \pm 1.48$ & $7.17 \pm 2.30$ & 0.103 \\
\hline Hct (\%) & 30.2 & $26.55 \pm 2.33$ & $21.81 \pm 7.53$ & $19.07 \pm 6.26$ & $\begin{array}{l}16.60 \pm \\
4.10\end{array}$ & $21.93 \pm 6.70$ & 0.250 \\
\hline MCV (fL) & 80.7 & $89.15 \pm 1.48$ & $72.34 \pm 6.56$ & $\begin{array}{l}71.71 \pm \\
16.74\end{array}$ & $\begin{array}{l}73.20 \pm \\
4.80\end{array}$ & $71.09 \pm 10.32$ & 0.183 \\
\hline MCH (pg) & 27.60 & $32.10 \pm 0.14$ & $24.79 \pm 4.71$ & $24.24 \pm 6.66$ & $\begin{array}{l}23.40 \pm \\
2.26\end{array}$ & $23.19 \pm 3.87$ & 0.206 \\
\hline $\mathrm{MCHC}(\mathrm{g} / \mathrm{dl})$ & 34.30 & $36.00 \pm 0.42$ & $34.23 \pm 5.22$ & $33.52 \pm 2.23$ & $\begin{array}{l}31.95 \pm \\
1.06\end{array}$ & $32.56 \pm 2.23$ & 0.154 \\
\hline RDW & 26.40 & $24.05 \pm 3.75$ & $25.32 \pm 10.2$ & $29.54 \pm 5.95$ & $\begin{array}{l}34.10 \pm \\
2.69\end{array}$ & $24.68 \pm 8.42$ & 0.706 \\
\hline
\end{tabular}

\section{TABLE 3: Hematological parameters between haplotypes in thalassemic patients}

RBC: Red blood cell count; Hb: Hemoglobin; Hct: Hematocrit; MCV: Mean cell volume; MCH: Mean cell hemoglobin; MCHC: Mean cell hemoglobin concentration; RDW: Red cell distribution width.

Further, post hoc analysis was performed to see the statistical significance among and in between the haplotypes for each of the hematological parameters. As the Cameroon haplotype had just one sample, it was removed from the post hoc analysis. Though no statistically significant relationship between all the haplotypes in terms of hematological parameters were found.

Post hoc analysis showed significant difference between Benin and Haplotype 1 (p-value 0.012), Benin and Haplotype 2 (p-value 0.018), and Benin and Senegal (p-value 0.011) Haplotype for the MCV parameter. Similarly, significant difference was seen between BEN and Haplotype 1 (p-value 0.039), BEN and Haplotype 2 (p-value 0.044), and BEN and SEN (p-value 0.018) Haplotype for the MCH parameter (Table is attached in the appendices section).

To find out if the most frequent haplotypes from our cohort (i.e., H1, H2, and Senegal) have some effects on red cell parameters, we analyzed the relationship between them and found no significant association (Figure 2). The reason behind grouping H1, H2 and Senegal haplotypes was to find out if these haplotypes showed any differences in the red cell parameters, as together they formed the major number of samples $(\mathrm{N}=$ $55)$. 


\section{Cureus}

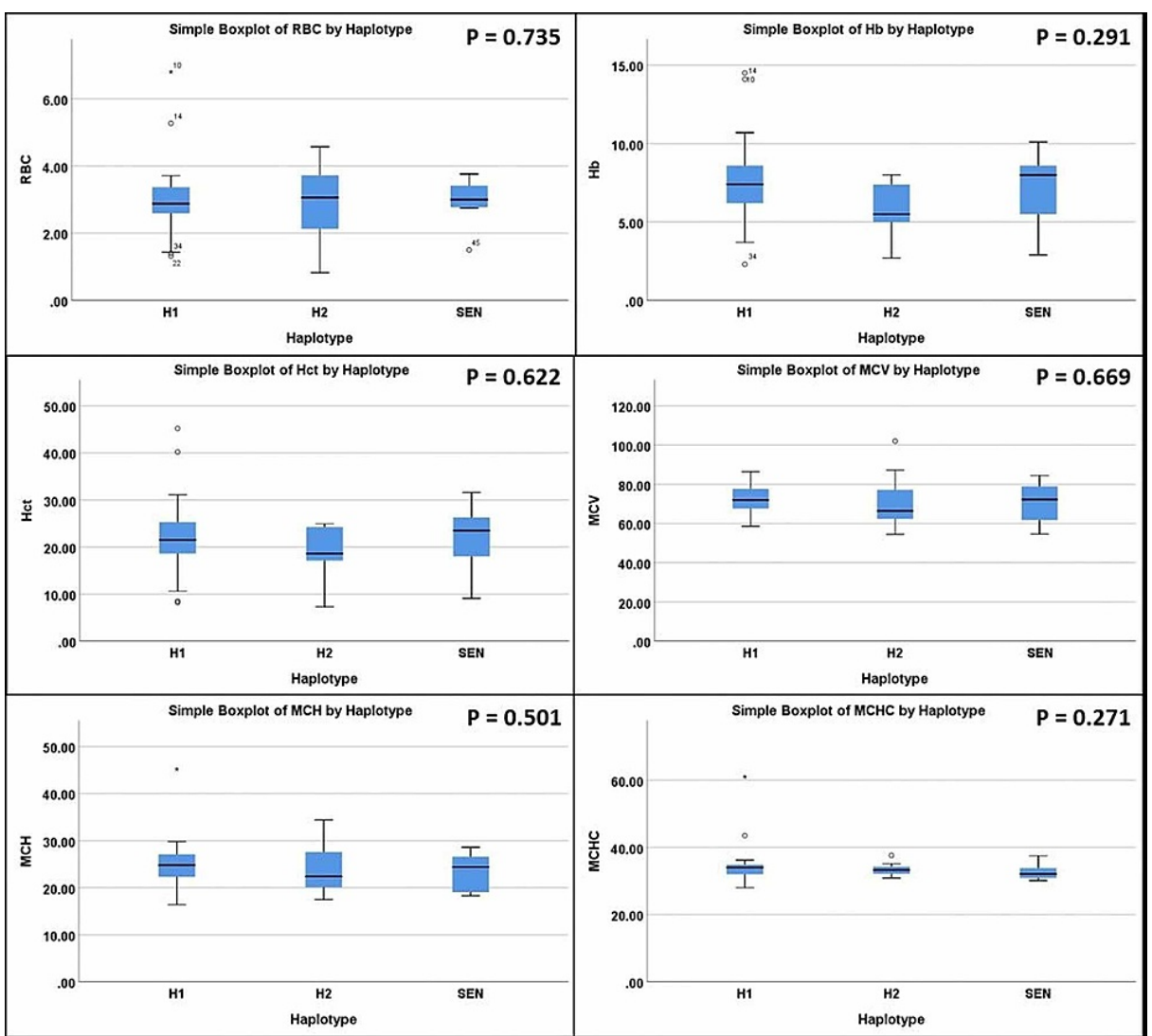

FIGURE 2: Comparison between the most frequent haplotypes $(\mathrm{H} 1, \mathrm{H} 2$, and Senegal) and the hematological parameters

Further, a multinomial logistic regression analysis was used to analyze the association of HBB haplotypes with changes in the red cell parameters including RBC, Hb, Hct, MCV, MCH, and MCHC (Table 4). As can be seen from the significance (Sig.) column, there was no significant association between the changes in levels of the red cell parameters according to the haplotype. This indicates that red cell parameters are independent of HBB haplotype. 


\section{Cureus}

\begin{tabular}{|c|c|c|c|c|c|c|c|}
\hline \multirow{2}{*}{ Haplotype $^{a}$} & \multirow{2}{*}{ Variable } & \multirow{2}{*}{ B } & \multirow{2}{*}{ Std. Error } & \multirow{2}{*}{ Sig. } & \multirow{2}{*}{$\operatorname{Exp}(B)$} & \multicolumn{2}{|c|}{ 95\% Confidence Interval for Exp (B) } \\
\hline & & & & & & Lower Bound & Upper Bound \\
\hline BEN & \multirow{5}{*}{ RBC } & 34.71803 & 486177.2 & 0.999943 & $1.2 E+15$ & 0 &.$b$ \\
\hline CAM & & -53.5923 & 65190.05 & 0.999344 & 5.31E-24 & 0 &.$b$ \\
\hline H1 & & 6.623199 & 5.313543 & 0.21259 & 752.3479 & 0.022569552 & 25079246.18 \\
\hline H2 & & 393.0014 & 184556.5 & 0.998301 & $4.7 \mathrm{E}+170$ & 0 &.$b$ \\
\hline H3 & & -184.941 & 238438.9 & 0.999381 & $4.8 \mathrm{E}-81$ & 0 &.$b$ \\
\hline BEN & \multirow{5}{*}{$\mathrm{Hb}$} & 55.13301 & 175784 & 0.99975 & $8.79 \mathrm{E}+23$ & 0 &.$b$ \\
\hline CAM & & 3.35179 & 71006.04 & 0.999962 & 28.5538 & 0 &.$b$ \\
\hline H1 & & 3.287009 & 2.782163 & 0.237421 & 26.7627 & 0.114643263 & 6247.572354 \\
\hline H2 & & -115.81 & 69158.65 & 0.998664 & $5.06 \mathrm{E}-51$ & 0 &.$b$ \\
\hline H3 & & 31.30258 & 254701.5 & 0.999902 & 3.93E+13 & 0 &.$b$ \\
\hline BEN & \multirow{5}{*}{ Het } & -22.8203 & 85898.53 & 0.999788 & $1.23 \mathrm{E}-10$ & 0 &.$b$ \\
\hline CAM & & 6.54563 & 33057.49 & 0.999842 & 696.195 & 0 &.$b$ \\
\hline H1 & & -2.01847 & 1.383707 & 0.144637 & 0.132859 & 0.008822198 & 2.000799385 \\
\hline H2 & & -20.9398 & 27749.34 & 0.999398 & 8.05E-10 & 0 &.$b$ \\
\hline H3 & & 14.9643 & 71759.27 & 0.999834 & 3154378 & 0 &.$b$ \\
\hline BEN & \multirow{5}{*}{ MCV } & -16.2453 & 12167.73 & 0.998935 & 8.81E-08 & 0 &.$b$ \\
\hline CAM & & -2.81946 & 15091.12 & 0.999851 & 0.059638 & 0 &.$b$ \\
\hline H1 & & 0.628306 & 0.695302 & 0.366184 & 1.874432 & 0.479763741 & 7.323388891 \\
\hline H2 & & 38.89905 & 36003.64 & 0.999138 & 7.83E+16 & 0 &.$b$ \\
\hline H3 & & 57.65269 & 44585.15 & 0.998968 & 1.09E+25 & 0 &.$b$ \\
\hline BEN & \multirow{5}{*}{$\mathrm{MCH}$} & 55.41141 & 63554.36 & 0.999304 & 1.16E+24 & 0 &.$b$ \\
\hline CAM & & 3.435909 & 31252.32 & 0.999912 & 31.05962 & 0 &.$b$ \\
\hline H1 & & -0.98305 & 1.863935 & 0.597912 & 0.374168 & 0.009693549 & 14.4428076 \\
\hline H2 & & -75.2429 & 95184.25 & 0.999369 & $2.1 \mathrm{E}-33$ & 0 &.$b$ \\
\hline H3 & & -169.735 & 126694.6 & 0.998931 & 1.93E-74 & 0 &.$b$ \\
\hline BEN & \multirow{5}{*}{$\mathrm{MCHC}$} & -46.6824 & 32312.69 & 0.998847 & 5.32E-21 & 0 &.$b$ \\
\hline CAM & & -2.6258 & 15729.97 & 0.999867 & 0.072382 & 0 &.$b$ \\
\hline H1 & & 0.430873 & 1.120979 & 0.700703 & 1.5386 & 0.17098069 & 13.84536686 \\
\hline H2 & & 66.47738 & 65618.41 & 0.999192 & 7.43E+28 & 0 &.$b$ \\
\hline H3 & & 106.45 & 103533.7 & 0.99918 & $1.7 \mathrm{E}+46$ & 0 &.$b$ \\
\hline
\end{tabular}

TABLE 4: Effect of each haplotype on RBC, HB, and HCT levels in thalassemia group using logistic regression model

a The reference category is: SEN

B - coefficient for the constant (intercept), S.E. - Standard error around B, Sig. - Significance, df -Degrees of freedom for the Wald chi-square test, $\operatorname{Exp}(B)-$ Exponentiation of the $B$ coefficient, which is an odds ratio. 


\section{Discussion}

Our study was designed to determine the HBB haplotype among $\beta$-thalassemia patients and to analyze their effects on red cell parameters. Haplotype analysis has a statistical power because it reduces the association test dimensions. Rather than using genotyping individually, the haplotype analysis identifies common genetic features in a population [10]. Apart from this, several previous studies have shown that HBB haplotype analysis provides crucial information on genetic variations and haplotypes of different populations [20-22]. A study by Zhang et al., on genetic heterogeneity of HBB in various geographic populations of Yunnan in Southwestern China, identified seven different HBB haplotypes among $41 \beta$ thalassemic chromosomes, where haplotype I and haplotype V were more than $65 \%$ ( $28 \beta$-thalassemic chromosomes), while the remaining percentages were distributed to the other haplotypes [13]. Our study identified six haplotypes among $60 \beta$-thalassemic patients from the Saudi cohort. The distribution of HBB haplotypes among $\beta$-thalassemic patients in our study showed that haplotype 1 was the highest with $62 \%$ (37 samples). This was in accordance with studies by various groups in the Mexican, Turkish and Western Iranian population which identified haplotype 1 to be the most prevalent haplotype among $\beta$-thalassemia chromosomes although restriction sites pattern is different $[11,21,23]$. Haplotype analysis of $\beta$-thalassemia patients was carried out in Western Iran by analyzing the pattern of seven restriction sites through the HBB gene cluster. It was found that haplotype I was the most prevalent haplotype with $35.7 \%$ among $\beta$ -

thalassemia chromosomes followed by haplotype III with $28.6 \%$ [11]. A previous haplotype analysis of three common $\beta$-thalassemia mutations performed in Syrian patients found out four HBB haplotypes among the studied patients where haplotype I was the most frequent one [23].

The HBB haplotyping plays a role in the detection of severity level through observing the hematological parameters in hemoglobinopathies. The correlation between Arab-Indian haplotype and Benin haplotype indicated that the mean of RBC count was higher in Arab-Indian haplotype (3.9 million cells/mcL) than in Benin haplotype (3.0 million cells/mcL) indicating the milder form of this haplotype. Moreover, the mean $\mathrm{Hb}$ concentration was also higher in Arab-Indian haplotype (10.8 g/dl), than in Benin haplotype ( $8.4 \mathrm{~g} / \mathrm{dl})$. These differences in hematological parameters among the two haplotypes explained the diverse range in severity among HBB haplotypes [8]. In our study, the hematological parameters among the six haplotypes (Benin, Senegal, Cameroon, haplotype 1, haplotype 2, and haplotype 3) were investigated. The mean of RBC count was very close to about 3 million cells/mcL in all haplotypes except in haplotype 3 which was less than 2.5 million cells/mcL. The mean of $\mathrm{Hb}$ concentration in all haplotypes was above $7 \mathrm{~g} / \mathrm{dl}$, except haplotype 2 and haplotype 3 . The mean was lowest in haplotype 3 with $5.35 \mathrm{~g} / \mathrm{dl}$. It was higher than $9 \mathrm{~g} / \mathrm{dl}$ in Benin and Cameroon, which was consistent with $\mathrm{Hb}$ concentration for Benin haplotype in El-Hazmi findings [8]. The mean of Hct was almost similar for haplotype 2, haplotype 3 and Senegal at $\sim 20 \%$, whereas the lowest in haplotype 3 with $16.6 \%$ and greater than $25 \%$ in Benin and Cameron. Four haplotypes, haplotype 1, haplotype 2, haplotype 3, and Senegal showed similar MCV levels of nearly $72 \mathrm{fL}$, Benin and Cameroon had higher than 80 fL. Similarly, for MCH, haplotype 1, haplotype 2, haplotype 3, and Senegal showed similar levels at $24 \mathrm{pg}$, whereas Benin showed the highest with $32.1 \mathrm{pg}$ and Cameroon at second highest at $27 \mathrm{pg}$. Five haplotypes showed a narrow range of MCHC level 32-34 g/dl, but Benin had the highest level at $36 \mathrm{~g} / \mathrm{dl}$. Although there was no significant alteration in red cell parameters among all haplotypes, we have observed that RBC parameters of haplotype 3 were the most affected ones since the anemia was more severe than others. Furthermore, HBB haplotypes are known to influence the severity of HBB diseases through hematological parameters [24]. A previous study about the effect of HBB cluster haplotype on hematological and clinical features of HBB mutation that cause sickle cell anemia was performed on 113 black American adults. The study found that Bantu haplotype usually is commonly associated with a severe form of the disease more than Benin and Cameroon haplotype where blood parameters in Benin and Cameroon haplotypes were characterized by mild clinical severity [25]. Though there is no Bantus haplotype in our study, we had a similar result for Benin and Cameroon haplotype where there was no significant difference between the patients. Additionally, all the haplotypes showed no significant difference among themselves in terms of the red cell parameters. However, when a pair wise comparison of significance was performed for each of the hematological parameters, we observed significant difference between Benin and Haplotype 1, Benin and Haplotype 2, and Benin and Senegal Haplotype for only MCV and MCH parameters, indicating that there is significant difference in severity of $\beta$-thalassemia for only the Benin, Haplotype 1, Haplotype 2 and Senegal haplotype as indicated from the hematological parameters MCV and MCH.

\section{Conclusions}

Our study indicated the importance of finding out types of $\beta$-globin haplotypes as novel types being discovered. Though no statistically significant association was identified between all the haplotypes in terms of hematological parameters, but for MCV and MCH we identified in severity of $\beta$-thalassemia for only the Benin, Haplotype 1, Haplotype 2 and Senegal in the studied cohort. Our result is a preliminary analysis representing the distribution of $\beta(S)$ haplotypes in the Western province of Saudi Arabia and future studies need to be carried out on a larger population to detect the frequency of each specific mutation in each haplotype among $\beta$-thalassemia patients. This would help to re-address the question of the origin(s) of the $\beta$-thalassemia.

\section{Appendices}


Multiple Comparisons

LSD

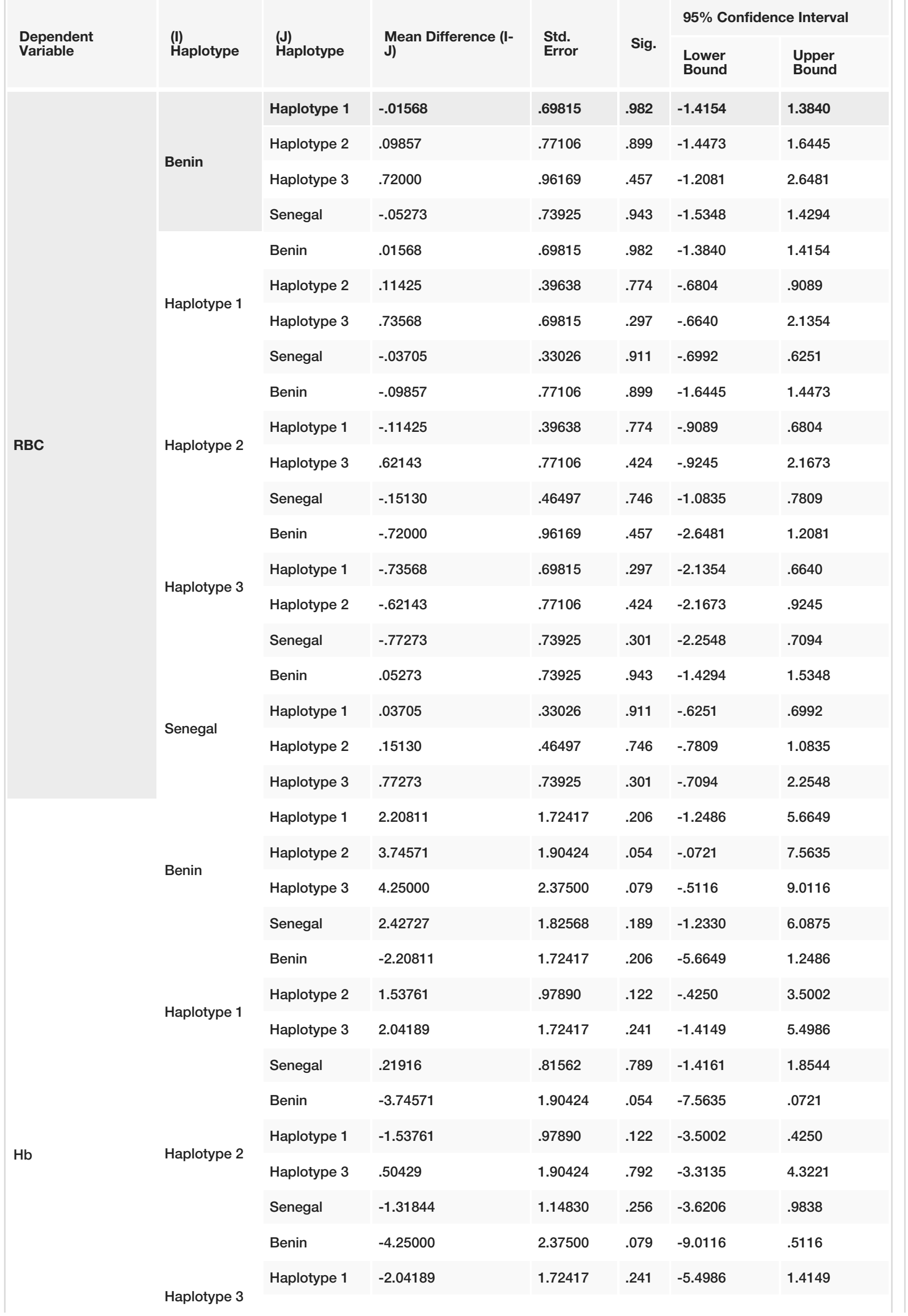




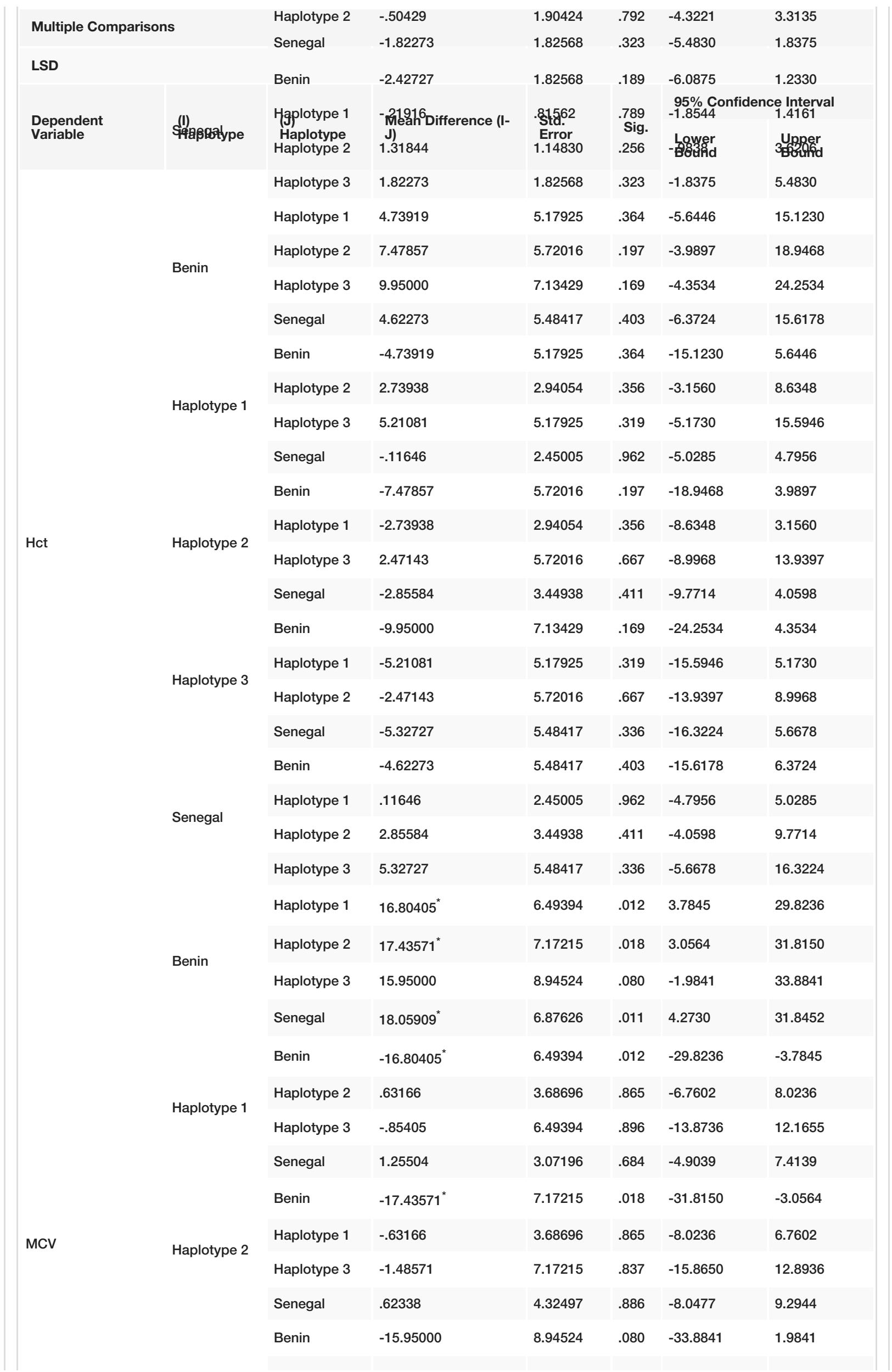




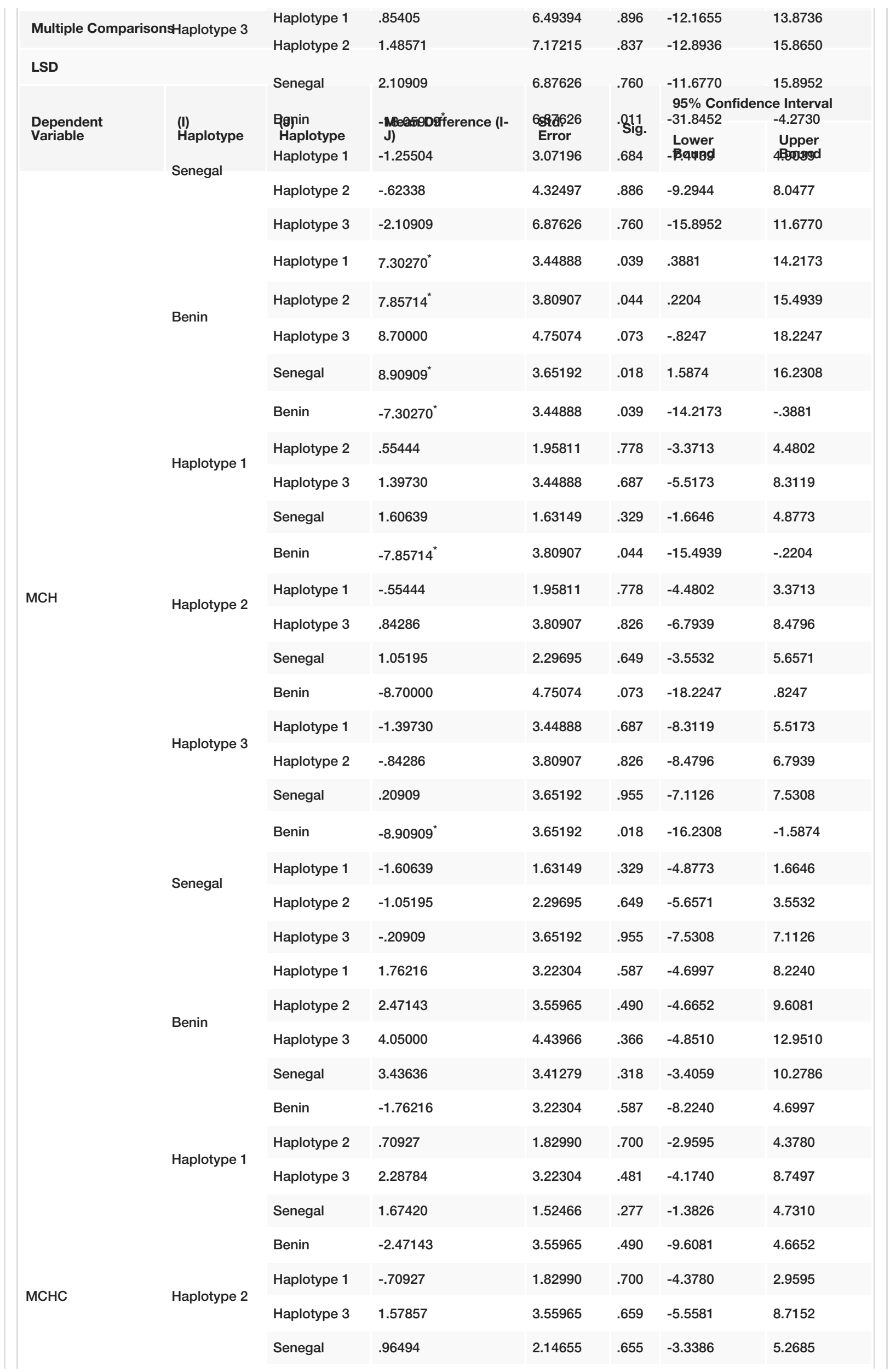




\section{Cureus}

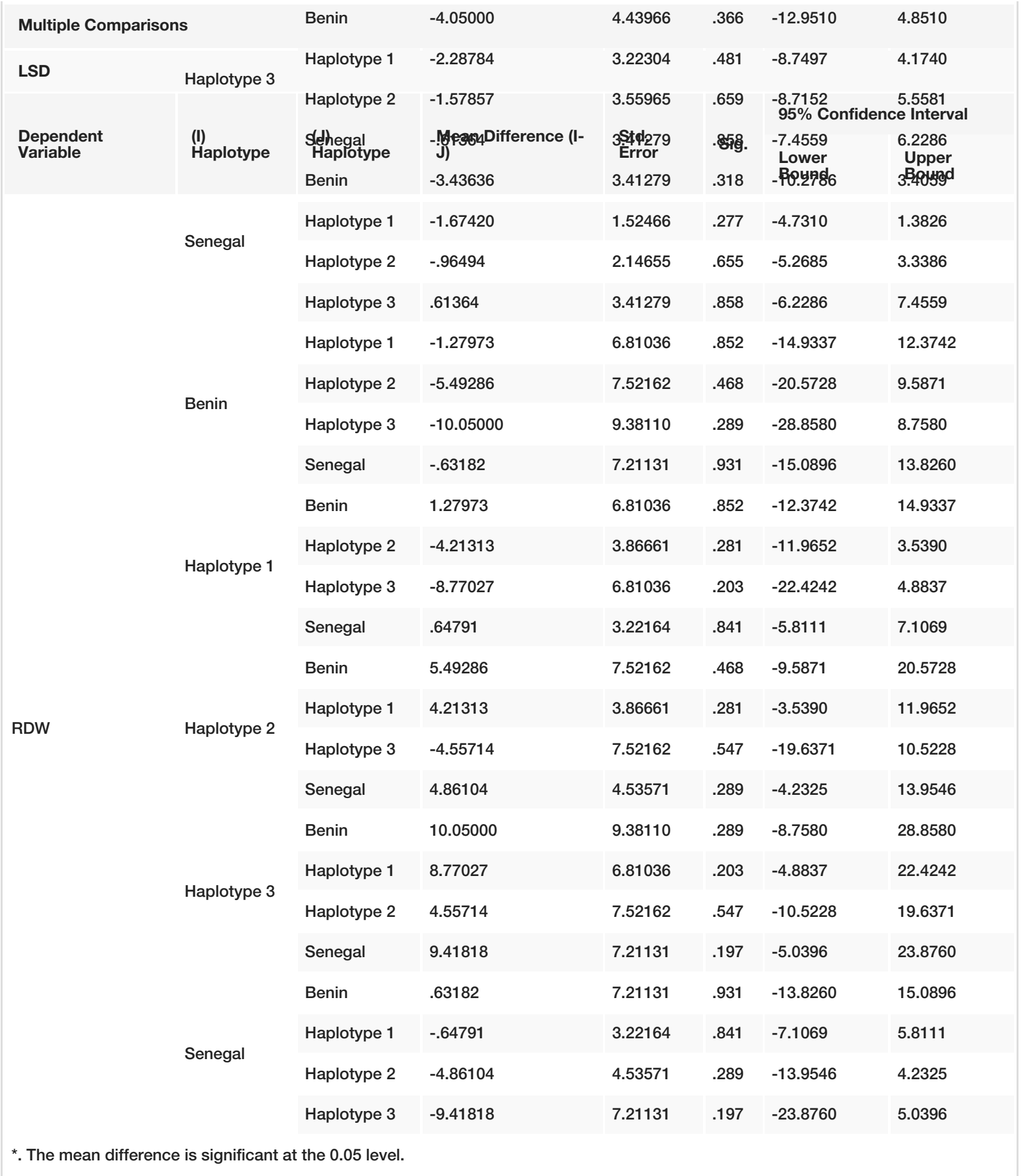

\section{TABLE 5: Post hoc analysis}

Post hoc analysis showed significant difference between Benin and haplotype I ( $p$-value 0.012), Benin and haplotype 2 ( $p$-value 0.018 ), and Benin and Senegal ( $p$-value 0.011 ) haplotype for the MCV parameter. Similarly, significant difference was seen between BEN and haplotype 1 ( $p$-value 0.039 ), BEN and haplotype 2 ( $p$-value 0.044 ), and BEN and SEN ( $p$-value 0.018 ) haplotype for the MCH parameter.

\section{Additional Information}

\section{Disclosures}

Human subjects: Consent was obtained or waived by all participants in this study. Ethics and Research Committee at Faculty of Applied Medical Sciences, King Abdulaziz University issued approval FAMS-2019003. Animal subjects: All authors have confirmed that this study did not involve animal subjects or tissue. Conflicts of interest: In compliance with the ICMJE uniform disclosure form, all authors declare the following: Payment/services info: All authors have declared that no financial support was received from any organization for the submitted work. Financial relationships: All authors have declared that they have 
no financial relationships at present or within the previous three years with any organizations that might have an interest in the submitted work. Other relationships: All authors have declared that there are no other relationships or activities that could appear to have influenced the submitted work.

\section{References}

1. Weatherall DJ: The definition and epidemiology of non-transfusion-dependent thalassemia . Blood Rev. 2012, 26:3-6. 10.1016/S0268-960X(12)70003-6

2. Olwi DI, Merdad LA, Ramadan EK: Thalassemia: a prevalent disease yet unknown term among college students in Saudi Arabia. J Community Genet. 2018, 9:277-282. 10.1007/s12687-017-0351-3

3. Memish ZA, Owaidah TM, Saeedi MY: Marked regional variations in the prevalence of sickle cell disease and $\beta$-thalassemia in Saudi Arabia: findings from the premarital screening and genetic counseling program. J Epidemiol Glob Health. 2011, 1:61-68. 10.1016/j.jegh.2011.06.002

4. Alsaeed ES, Farhat GN, Assiri AM, et al.: Distribution of hemoglobinopathy disorders in Saudi Arabia based on data from the premarital screening and genetic counseling program, 2011-2015. J Epidemiol Glob Health. 2018, 7:S41-S47. 10.1016/j.jegh.2017.12.001

5. Alnaami A, Wazqar D: Disease knowledge and treatment adherence among adult patients with thalassemia: a cross-sectional correlational study. Pielegniarstwo XXI wieku / Nursing in the 21st Century. 2019, 18:95101. 10.2478/pielxxiw-2019-0014

6. Aldakeel SA, Ghanem NZ, Al-Amodi AM, et al.: Identification of seven novel variants in the $\beta$-globin gene in transfusion-dependent and normal patients. Arch Med Sci. 2020, 16:453-459. 10.5114/aoms.2019.84825

7. Alafari H, Alenzi FQ: Biochemical and molecular analysis of the beta-globin gene and LCR region on Saudi $\beta$-thalassemia patients. Saudi J Biol Sci. 2020, 27:3106-3112. 10.1016/j.sjbs.2020.08.044

8. El-Hazmi MA: Beta-globin gene haplotypes in the Saudi sickle cell anaemia patients . Hum Hered. 1990, 40:177-186. 10.1159/000153927

9. Cox CB, Moore PD, Ladle R: Biogeography: An Ecological and Evolutionary Approach. John Wiley \& Sons, 2016.

10. Clark AG: The role of haplotypes in candidate gene studies . Genet Epidemiol. 2004, 27:321-333. 10.1002/gepi.20025

11. Rahimi Z, Muniz A, Akramipour R, Tofieghzadeh F, Mozafari H, Vaisi-Raygani A, Parsian A: Haplotype analysis of beta thalassemia patients in Western Iran. Blood Cells Mol Dis. 2009, 42:140-143. 10.1016/j.bcmd.2008.12.001

12. Lapouniéroulie C, Dunda O, Ducrocq R, et al.: A novel sickle cell mutation of yet another origin in Africa: the Cameroon type. Hum Genet. 1992, 89:333-337. 10.1007/BF00220553

13. Zhang J, He J, Zeng XH, et al.: Genetic heterogeneity of the beta-globin gene in various geographic populations of Yunnan in southwestern China. PloS ONE. 2015, 10:0122956. 10.1371/journal.pone.0122956

14. El-Hazmi MA, Al-Swailem AR, Warsy AS: Molecular defects in beta-thalassaemia in the population of Saudi Arabia. Hum Hered. 1995, 45:278-285. 10.1159/000154314

15. El-Harith EH, Kuhnau W, Schmidtke J, Stuhrmann M, Nasserallah Z, Al-Shahiri A: Identification and clinical presentation of beta thalassaemia mutations in the eastern region of Saudi Arabia. J Med Genet. 1999, 36:935-937.

16. Abuzenadah AM, Hussein IM, Damanhouri GA, et al.: Molecular basis of beta-thalassemia in the western province of Saudi Arabia: identification of rare beta-thalassemia mutations. Hemoglobin. 2011, 35:346-357. 10.3109/03630269.2011.588508

17. Sutton M, Bouhassira EE, Nagel RL: Polymerase chain reaction amplification applied to the determination of beta-like globin gene cluster haplotypes. Am J Hematol. 1989, 32:66-69. 10.1002/ajh.2830320113

18. Joly P, Lacan P, Garcia C, Delasaux A, Francina A: Rapid and reliable beta-globin gene cluster haplotyping of sickle cell disease patients by FRET Light Cycler and HRM assays. Clin Chim Acta. 2011, 412:1257-1261. 10.1016/j.cca.2011.03.025

19. Shaikho EM, Farrell JJ, Alsultan A, et al.: A phased SNP-based classification of sickle cell anemia HBB haplotypes. BMC Genomics. 2017, 18:608. 10.1186/s12864-017-4013-y

20. Lindenau JD, Wagner SC, de Castro SM, Hutz MH: The effects of old and recent migration waves in the distribution of HBB*S globin gene haplotypes. Genet Mol Biol. 2016, 39:515-523. 10.1590/1678-4685-gmb2016-0032

21. Bahadir A, Ozturk O, Atalay A, Atalay EO: Beta globin gene cluster haplotypes of the beta thalassemia mutations observed in Denizli province of Turkey. Turkish J Haematol. 2009, 26:129-137.

22. Nongbri SRL, Verma HK, Lakkakula B, Patra PK: Presence of atypical beta globin (HBB) gene cluster haplotypes in sickle cell anemia patients of India. Rev Bras Hematol Hemoter. 2017, 39:180-182. 10.1016/j.bjhh.2017.01.007

23. Murad H, Moassas F, Ghoury I, Mukhalalaty Y: Haplotype analysis of three common beta-thalassemia mutations in Syrian patients. Hemoglobin. 2018, 42:302-305. 10.1080/03630269.2018.1553789

24. Loggetto SR: Sickle cell anemia: clinical diversity and beta S-globin haplotypes . Rev Bras Hematol Hemoter. 2013, 35:155-157. 10.5581/1516-8484.20130048

25. Rieder RF, Safaya S, Gillette P, Fryd S, Hsu H, Adams JG III, Steinberg MH: Effect of beta-globin gene cluster haplotype on the hematological and clinical features of sickle cell anemia. Am J Hematol. 1991, 36:184-189. 10.1002/ajh.2830360305 